\title{
Spatial Distribution and Use of Agrodiversity in Family Gardens of Tixmucuy, Campeche, Mexico
}

\section{Gisela José-García}

Colegio de Postgraduados Campus Campeche

\section{Bernardino Candelaria-Martínez}

Tecnológico Nacional de México, Campus Chiná

CAROLINA FLOTA BAÑUELOS ( $\sim$ cflota@colpos.mx )

Colegio de Postgraduados Campus Campeche https://orcid.org/0000-0001-5533-6722

Jaime Bautista-Ortega

Colegio de Postgraduados Campus Campeche

\section{Verónica Rosales-Martínez}

Consejo Nacional de Ciencia y Tecnología-Colegio de Postgraduados Campus Campeche

\section{Research}

Keywords: Diversity, structure, function, background, agroecology

Posted Date: May 13th, 2020

DOI: https://doi.org/10.21203/rs.3.rs-28381/v1

License: (c) (i) This work is licensed under a Creative Commons Attribution 4.0 International License. Read Full License 


\section{Abstract \\ Background}

Family plots or gardens, often referred to as solars, are spaces surrounding a house, that contain a combination of plant and animal species distributed according to the family's needs. The objective of this work was to identify the structure, use, and agrodiversity of these family plots in the community of Tixmucuy, Campeche, Mexico.

\section{Methods}

Six plots of two previously identified types were randomly chosen. A semi-structured questionnaire was applied to family plot managers focusing on family demographic information and plot management. The data was statistically descriptive and the Shannon-Wiener diversity index was applied.

\section{Results}

It was observed that families are generally nuclear groups with 3.9 members, with the average age of housewives responsible for the family plots being 45 years of age. The plots have an average extension of $1,155 \mathrm{~m}^{2}$. Three species of birds were observed and were used for food, food-sale, and as pets. 95 plant species were registered and were used for food, wood, or ornamental purposes. In the vertical distribution the herbaceous stratus had the highest number of individuals (29.37), followed by bushy shrubs with 15.2 and arboreal with 7.83 individuals. The importance of the elements and the overall organizational management of the plot by the family determine the horizontal distribution.

\section{Conclusions}

The importance of Tixmucuy's family plots lies in the generation of ecosystem services to the family, for which they use plant and animal species in a design that facilitates their management and interaction.

\section{Background}

The presence and permanent participation of family members in the management of family plots results in intensive management of this system, thus fostering dynamic changes in the structure, diversity, and interaction of its components (Caballero-Serrano et al., 2016). The management and variation of different components are associated with cultivating food, recreation, and generating economic income by smallscale sale within and outside the community (Albuquerque, Andrade, \& Caballero, 2005; Rangel-landa, Casas, Rivera-Lozoya, Torres-García, \& Vallejo-Ramos, 2016). Family solares represent a strategy to diversify income and decrease reliance on a single economic activity (Abebe, Sterck, Wiersum, \& Bongers, 2013). In this sense, it has been reported that in Calakmul, Campeche these systems comprise between 
12 and $18 \%$ of the total income for peasant families (Wossen et al., 2014). In addition to food and income generation, family plots allow the development of traditional practices such as the medicinal and mystical, or ceremonial, use of flora (Moreno-calles et al., 2016). It has been proposed that there is a relationship between the size of the families, the migration of one of its members (Cano Contreras \& Siqueiros Delgado, 2009), and the size of the area intended for the implementation and management. To compliment this proposed relationship the presence, distribution, and use of the components that make up the family plots are also considered. Fernandes \& Nair, (1986), Flota-Bañuelos et al. (2016), and Chablé Pascual et al. (2015) emphasize the importance of identifying the vertical and horizontal structure of family plots, which reflects the distribution in the area and the height of the components, in order to determine the interactions and dynamics of these systems.

In family plots in southeastern Mexico, 27 to 602 plant species of different taxonomic groups and growth habits have been recorded (Huerta \& van der Wal, 2012; Pulido-Salas, by Jesús Ordóñez Díaz, \& de Dios, 2017). With regard to the animal composition, Chablé Pascual et al. (2015) reported the presence of domestic and wild animal species, which are mainly used for consumption. From this perspective, it is proposed that the knowledge of the structure and diversity of the components of family plots, is fundamental to develop strategies that allow for the improvement of their management and productivity, as well as the design of government strategies focused on strengthening family gardens to increase the well-being of the rural population (Cruz-Bautista, Casanova-Pérez, Pablo Martínez-Dávila, Flores-Martínez, \& Villegas-Rodríguez, 2019). Therefore, the objective of this work was to identify the diversity, structure, and use of plant and animal composition in the family plots of Tixmucuy, Campeche, Mexico.

\section{Methods}

\section{Área de estudio}

The study was conducted from August 2016 to July 2017 in the town of Tixmucuy, Campeche, located at $19^{\circ} 34^{\prime} 54.57^{\prime \prime} \mathrm{N} 90^{\circ} 18^{\prime} 59.81^{\prime \prime} \mathrm{W}$, with an average annual temperature and precipitation of $26.4^{\circ} \mathrm{C}$ and $1,120 \mathrm{~mm}$ (National Institute of Statistics and Geography and Information, 2015), and altitude of 30 msnm (García, 1973). In the town, there is a total population of 497 inhabitants distributed in 142 homes, of which $13.38 \%$ have ground floor, $24.65 \%$ lack drainage, $5.63 \%$ lack electricity, $9.86 \%$ do not have access to piped water and $7.75 \%$ do not have sanitation services (INEGI, 2015). In the community, the main economic activity is agriculture, followed by small-scale livestock (beekeeping) (INEGI, 2015).

For the selection of plots, a reporting by Flota-Bañuelos et al. (2016) suggested previously identified plots and mentioned that there are two different groups of family plots in the state of Campeche: Group 1 (G1) average area of 2,695 $\mathrm{m}^{2}$, average of 11.5 and 2.7 plant and animal species, and Group 2 (G2) average area of $606 \mathrm{~m}^{2}, 8.5$ and 2.1 plant species and on average. Six family plots were selected, three for $\mathrm{G} 1$ and three for G2, following the method proposed by Eisenhardt (1989) and Gutierrez-Triay et al. (2007). For an overview of the design and management of family plots, a semi-structured questionnaire with open and closed questions, composed of four sections was developed: 1) general information, 2) presence, 3) 
handling, and 4) use of the plant and animal component in the site. An in-depth interview with heads of the families was also conducted following the recommendations of González-Ortiz, Pérez-Magaña, Ocampo-Fletes, Paredes-Sánchez, \& de la Rosa-Peñaloza (2014). The interviews were accompanied by a tour of the plots. Questionnaire data was captured in a Microsoft Office Excel 2013 workbook.

\section{Registration and identification of plant and animal species}

The common name, scientific name, and use of plant species present in family plots were recorded. The height was measured with a clinometer (Suunto, Model pm5/360PC), stem diameter at $1.3 \mathrm{~m}$ height with a diametric tape and the cup diameter with a tape measure taking the longest distance between the ends of the cup. Photos and samples of the different parts of the less common plants were taken for identification by specialized herbarium staff of the Autonomous University of Campeche. The animals of each family plot were recorded by species and the general purpose given to them by the family (personal consumption, sale, or pets).

\section{Horizontal and vertical structure of family plots}

A GPS-Garmin ® E-trex 20 model was used to record the coordinates of the six plots. Shrubs, herbaceous and trees that made up the plant component and infrastructure were georeferenced as well. Subsequently, a family site was randomly selected from each of the two groups (G1 and G2), to schematically represent the distribution of its composition, as well as the vertical and horizontal structure.

A descriptive analysis was performed of all species of the site (diversity, uses of plant and animal species, and species present by stratum between plots of the two groups). To determine plant and animal diversity indices in the two groups of plots, the Shannon-Wiener diversity index was calculated with the statistical package (PAST Version 1.95).

\section{Results}

The selected families are nuclear and are made up of approximately $3.6 \pm 3.4$ and $4.3 \pm 0.7$ members in $\mathrm{G} 1$ and $\mathrm{G} 2$, housewives are responsible for the maintenance of the plot, with average ages of de $48 \pm 13$ and $42.66 \pm 28$ years in the $G 1$ and $G 2$ respectively. In relation to the family plot, $83 \%$ of the families surveyed built its plots on lands with ejidal-type tenure and $17 \%$ on private property the extent of the plots range from 1,033.24 \pm 541.24 and 1,278.85 $\pm 614.91 \mathrm{~m}^{2}$ in G1 and G2; and have inhabited the grounds for $17.66 \pm 2.66$ years in the $\mathrm{G} 1$ and $21 \pm 2.6$ years in the $\mathrm{G} 2$ (Fig. 1 ).

\section{Diversity and use of plant species}

A total of 470 plant organisms belonging to 95 species and 43 botanical families were recorded (Table 1). The most represented families were the Fabaceae and Rutaceae with $8.4 \%$ each, followed by Solanaceae and Anacardiaceae with 6.3 and $5.2 \%$, respectively (Table 1). It was also observed, that families make nine different uses of plant species, the main being ornamental and food for human consumption, 
followed by food-sale, shade, medicinal purposes, wood, fuel, seasoning, and construction of traditional dwellings (Fig. 2). 
Table 1

List of plant species present in the plots of Tixmucuy, Campeche

\begin{tabular}{|c|c|c|c|}
\hline Family & Scientific name & Common name & Use \\
\hline Acanthaceae & Justicia spicigera Schltdl. & $\begin{array}{l}\text { Ych-kaan } \\
\text { (trompetilla) }\end{array}$ & $\mathrm{O}, \mathrm{Me}$ \\
\hline Amaranthaceae & $\begin{array}{l}\text { Dysphania ambrosioides L. Mosyakin \& } \\
\text { Clemants }\end{array}$ & Epazote & A, Me, C \\
\hline \multirow[t]{3}{*}{ Amaryllidaceae } & Zephyranthes carinata Herb. & Brujitas & 0 \\
\hline & Allium schoenoprasum L. & Cebollina & 0 \\
\hline & Zephyranthes rosea Lindl. & Lirio de lluvia & 0 \\
\hline \multirow[t]{5}{*}{ Anacardiaceae } & Mangifera Indica L. & Mango criollo & $\mathrm{A}, \mathrm{A}-\mathrm{V}, \mathrm{S}, \mathrm{Ma}$ \\
\hline & Mangifera caesia Jack & Mango ataulfo & $A, A-V, S, C b$ \\
\hline & Anacardium occidentale $\mathrm{L}$ & Marañon & $A, A-V, S$ \\
\hline & Spondias purpurea L. & $\begin{array}{l}\text { Ciruela } \\
\text { campechana }\end{array}$ & $A, A-V$ \\
\hline & Spondias mombin L. & Ciruela chiabal & $A, A-V$ \\
\hline \multirow[t]{3}{*}{ Annonaceae } & Annona muricata L. & Guanabana & $A, A-V, S$ \\
\hline & Annona purpurea Moc. \& Sessé ex Dunal & Anona & A, S \\
\hline & Malmea depressa (Baillon) R.E.Fr. & Cilantro & $A, C$ \\
\hline \multirow[t]{2}{*}{ Apocynaceae } & $\begin{array}{l}\text { Tabernaemontana divaricata (L) R. Br. Ex } \\
\text { Roem. \& Schult }\end{array}$ & Clavel & 0 \\
\hline & Adenium obesum (Forssk.) Roem. \& Schult. & Rosa del desierto & 0 \\
\hline \multirow[t]{4}{*}{ Araceae } & Dieffenbachia maculata (Loodd.) G. Don & $\begin{array}{l}\text { Difenbaquia, } \\
\text { banderita }\end{array}$ & 0 \\
\hline & Chamaedorea elegans Mart. & $\begin{array}{l}\text { carrizo/palmera de } \\
\text { salón }\end{array}$ & 0 \\
\hline & Cocos nucifera L. & Coco & A, S \\
\hline & $\begin{array}{l}\text { Coccothrinax crinita (Griseb. \& H. Wendl. ex } \\
\text { Kerch.) Becc. }\end{array}$ & Huano & Cvt \\
\hline \multirow[t]{4}{*}{ Asteraceae } & Tithonia diversifolia (Hamsley.) A. Gray & Árnica & 0 \\
\hline & Chrysanthemum leucanthemum $\mathrm{L}$. & Margaritas & 0 \\
\hline & Chrysanthemum Maximum Ramond & Margaritón & 0 \\
\hline & Dahlia pinnata Cav. & Dalia & 0 \\
\hline
\end{tabular}




\begin{tabular}{|c|c|c|c|}
\hline \multirow[t]{3}{*}{ Asparagaceae } & Sansevieria trifasciata Prain & Lengua de suegra & 0 \\
\hline & Cordyline terminalis (L.) Kunth. & Palmita roja & 0 \\
\hline & Agave angustifolia Haw. & Maguey Verde & 0 \\
\hline \multirow[t]{2}{*}{ Asphodelaceae } & Aloe vera (L.) Burm. f. & Sábila & Me \\
\hline & Aloe arborescens Mill. & $\begin{array}{l}\text { Sábila de } \\
\text { ornamental }\end{array}$ & 0 \\
\hline Balsaminaceae & Impatiens hawkeri A. Rich. & Flor jaspeada & 0 \\
\hline Bixaceae & Bixa Orellana L. & Achiote & $A, C$ \\
\hline Bignoniaceae & Tabebuia rosea Juss. & Maculis & $\begin{array}{l}\text { O, Ma, S, Cb, } \\
\text { Cvt }\end{array}$ \\
\hline Boraginaceae & Ehretia tinifolia L. & Roble & $\begin{array}{l}\text { Ma, S, Cb, } \\
\text { Cvt }\end{array}$ \\
\hline \multirow[t]{4}{*}{ Cactaceae } & Coryphantha georgii Boed. & Cactus & 0 \\
\hline & Schlumbergera buckleyi (T moore) T. Jaden. & Cactus navidad & 0 \\
\hline & Opuntia ficus-indica (L.) Mill. & Nopal & $A$ \\
\hline & Opuntia monacantha Haw & Nopalito & $A$ \\
\hline Combretaceae & Terminalia catappa L. & Almendra & $A, 0, S$ \\
\hline Crassulaceae & Echeveria glauca (Baker) E. Morren & Rosa enana & 0 \\
\hline \multirow[t]{3}{*}{ Euphorbiaceae } & Euphorbia mili Des Moul. & Corona de cristo & 0 \\
\hline & Euphorbia pulcherrima Willd. ex Klotzsch & Noche buena & 0 \\
\hline & Cnidoscolos chayamansa McVaugh. & Chaya & $\mathrm{A}, \mathrm{Me}, \mathrm{A}-\mathrm{V}$ \\
\hline \multirow[t]{8}{*}{ Fabaceae } & Crotalaria longirostrata Hook. \& Arn. & Chipilín & A \\
\hline & $\begin{array}{l}\text { Bauhinia herrerae (Britton \& Rose) Standl. \& } \\
\text { Steyerm }\end{array}$ & Cola de gato & $\mathrm{Ma}, \mathrm{Cb}$ \\
\hline & Piscidia piscipula (L.) Sarg. & Jabín & Ma \\
\hline & Lonchocarpus rugosus Benth. & Kanasín & Ma, S, Cvt \\
\hline & Cassia fistula L. & Lluvia de oro & 0 \\
\hline & Tamarindus indica L. & Tamarindo & $A, A-V, S$ \\
\hline & Senna fruticosa (Mill.) H.S. Irwin \& Barneby & Tuu ja'abin & 0 \\
\hline & Cassia racemosa Mill. & Ya'ax Ja'abin & $\mathrm{Ma}, \mathrm{Cb}, \mathrm{Cvt}$ \\
\hline Heliconiaceae & Heliconia latispatha Benth. & Platanillo & 0 \\
\hline Lamiaceae & Ocimum basilicum $\mathrm{L}$. & Albahaca & $\mathrm{O}, \mathrm{Me}$ \\
\hline
\end{tabular}




\begin{tabular}{|c|c|c|c|}
\hline & Ocimum micranthum Willd. & $\begin{array}{l}\text { Albahaca de } \\
\text { monte }\end{array}$ & $\mathrm{O}, \mathrm{Me}$ \\
\hline & Coleus blumei Benth. & Cóleo, cretona & 0 \\
\hline & Mentha citrata Ehrh. & Hierbabuena & $\mathrm{C}, \mathrm{Me}$ \\
\hline & Lippia dulcis Trevir. & Orégano de castilla & C \\
\hline Lauraceae & Persea americana Mill. & Aguacate & $A, A-V, S$ \\
\hline \multirow[t]{2}{*}{ Lythraceae } & Lagerstroemia indica L. & Astromelia & 0 \\
\hline & Lafoensia speciosa J. St.-Hil. & Lolón & $\mathrm{Ma}, \mathrm{S}$ \\
\hline Malpighiaceae & Byrsonima crassifolia (L.) Kunth. & Nance & $A, A-V$ \\
\hline \multirow[t]{2}{*}{ Malvaceae } & Althaea rosea (L.) Cav. & Flor de Veracruz & 0 \\
\hline & Hibiscus rosa-sinensis $\mathrm{L}$. & Tulipán & 0 \\
\hline Milaceae & Cedrela odorata L. & Cedro & Ma, Cvt \\
\hline Moraceae & Brosimum alicastrum Sw. & Ramón & $\mathrm{S}, \mathrm{Cb}$ \\
\hline \multirow[t]{3}{*}{ Musaceae } & Musa sapientum L. & Plátano macho & $A, A-V$ \\
\hline & Musa sapientum var. Champa Baker & Plátano manzano & $A, A-V$ \\
\hline & Musa paradisiaca L. & Plátano Roatán & $A, A-V$ \\
\hline Myrtaceae & Psidium guajava $\mathrm{L}$. & Guayaba & $\mathrm{A}, \mathrm{Cb}$ \\
\hline \multirow[t]{2}{*}{ Petiveriaceae } & Petiveria alliacea L. & Hoja de zorrillo & Me \\
\hline & Eichhornia crassipes (Mart.) Solms & Lirio acuático & 0 \\
\hline Portulacaceae & Portulaca halimoides L. & Mañanitas & 0 \\
\hline Poaceae & Saccharum officinarum $\mathrm{L}$. & Caña & A \\
\hline \multirow[t]{2}{*}{ Rubiácea } & Cosmocalyx spectabilis Standl. & Chacté & 0 \\
\hline & Hamelia patens Jacq. & Ix'kanan & $\mathrm{O}, \mathrm{Me}$ \\
\hline \multirow[t]{6}{*}{ Rutaceae } & Citrus aurantifolia Swingle & Limón indio & $A, A-V$ \\
\hline & Citrus x latifolia Tanaka ex Q. Jiménez & Limón persa & $A, A-V$ \\
\hline & Murraya paniculata (L.) Jack & Limonaria & 0 \\
\hline & Citrus reticulata Blanco. & Mandarina & $A, A-V$ \\
\hline & Citrus aurantium L. & Naranja agria & $A, A-V$ \\
\hline & Citrus sinesis (L.) Osbek & Naranja dulce & $A, A-V$ \\
\hline
\end{tabular}




\begin{tabular}{|c|c|c|c|}
\hline & Ruta chalepensis $\mathrm{L}$. & Ruda & $\mathrm{Me}$ \\
\hline & Citrus x paradisi Macfad. & Toronja & $A, A-V$ \\
\hline Rosaceae & Rosa chinensis Jacq. & Rosas & 0 \\
\hline \multirow[t]{2}{*}{ Sapindaceae } & Sapindus saponaria L. & Caimito & $A, A-V$ \\
\hline & Melicoccus bijugatus Jacq. & Huaya de monte & $A, A-V$ \\
\hline Sapotaceae & $\begin{array}{l}\text { Chrysophyllum mexicanum Brandegee ex } \\
\text { Standl. }\end{array}$ & Caimito de monte & $A$ \\
\hline \multirow[t]{6}{*}{ Solanaceae } & Brugmansia candida Pers. & $\begin{array}{l}\text { Árbol de las } \\
\text { trompetas }\end{array}$ & 0 \\
\hline & $\begin{array}{l}\text { Capsicum annuumvar Frutescens (L.) } \\
\text { Kuntze. }\end{array}$ & Chile bolita & $A$ \\
\hline & Capsicum annuum var. Annuum & Chile dulce & $A$ \\
\hline & Capsicum chinense Jacq. & Chile habanero & A \\
\hline & Capsicum annum L. & Chile Max & $A$ \\
\hline & Solanum lycopersicum L. & Tomate & A \\
\hline Urticaceae & Soleirolia soleirolii (Req.) Dandy & Piojera & 0 \\
\hline \multirow[t]{2}{*}{ Verbenaceae } & Verbena peruviana $(\mathrm{L})$ Britton & Bejuquillo & $\mathrm{Me}$ \\
\hline & Lippia graveolens Kunth & Orégano & $\mathrm{C}$ \\
\hline Zamiaceae & Dioon edule Lindl. & Palma & 0 \\
\hline
\end{tabular}

Comparing diversity by the two different groups of family plots, greater diversity was observed in G2 $\left(H^{\prime}=3,983\right.$ vs $H^{\prime}=2.89$, respectively). With regard to the number of plants per group, it was observed that, in G1, the most abundant are Rosa chinensis Jacq., for ornamental use (20\%), Saccharum officinarum L., for use as food (18\%) and Cedrela odorata L., for Woody use and construction (15.6\%). In turn in G2, the greatest uses are of Citrus x latifolia Tanaka ex Q. Jiménez plants as food and food-sale (5.8\%), Musa sapientum var. Champa Baker as food and food-sale (5.8\%) and Chenopodium ambrosioides L. (= Teloxis ambrosoides (L.) W.A. Weber) used as food, seasoning, and medicine (5.8\%).

\section{Diversity and use of animal species}

A total of 44 animal specimens, including over three species, belonging to the Phasianidae and Anatidae were recorded. Being the most abundant species. Gallus domesticus L. (70\%) was used for food and food-sale, followed by Meleagris gallopavo L. (25\%) for food and food use, and Dendrocygna autumnalis 
$(5 \%)$ as a pet. Of the total of the observed individuals, $91 \%$ corresponded to G1 where the three species were designed and $9 \%$ to $\mathrm{G} 2$ with a registered species.

\section{Vertical structure of family plots}

Three strata were observed within the family plots: arboreal, shrub, and herbaceous. The stratum with the greatest abundance was the herbaceous with 29.37 plants, followed by the shrub with 15.2 and the arboreal with 7.83 individuals. The stratum with the highest number of species observed was the herbaceous with $36.5 \%$ of the total species recorded, followed by shrub and herbaceous with 34.3 and $29.2 \%$ (Table 2). When the vertical structure was described, it was observed that in the G1, tree and shrub species had heights less than $10 \mathrm{~m}$, while in $\mathrm{G} 2$ trees with heights greater than $10 \mathrm{~m}$. were recorded. This difference is due to the age of the plots; the $G 1$ is 10 years old and the $G 2$ is 47 years old established and managed (Fig. 2A and 2B).

\section{Tree stratum}

In this stratum three, height ranges were considered high, medium and low. For G1, plants of the high range comprised heights of 10.45 to $10.95 \mathrm{~m}$ (Cocos nucifera L., Tabebuia rosea Juss. and Psidium guajava L.), the medium heights were 6 to $7.70 \mathrm{~m}$ (Mangifera caesia Jack., Anacardium occidentale L. and Tamarindus indica L.), and those of the low range had heights less than $4.82 \mathrm{~m}$ (Lafoensia speciosa J. St.-Hil. and Murraya paniculata L. Jack). In G2, the highest-altitude species had a range of 10 to $17 \mathrm{~m}$ (Persea americana Mill., Cedrela odorata L. and Brosimum alicastrum Sw.), medium species with height from 5.0 to $9.90 \mathrm{~m}$ (Mangifera indica L., Chrysophyllum mexicanum Brandegee ex Standl. and Piscidia piscipula L. Sarg) and species of the low range with heights of 1.80 to $4.0 \mathrm{~m}$ (Ehretia tinifolia L., Psidium guajava L. and Citrus x paradisi Macfad).

\section{Shrub stratum}

The maximum height of this stratum was $5 \mathrm{~m}$ and the minimum $3 \mathrm{~m}$. and were grouped into two ranges; the first was between 3 to $4 \mathrm{~m}$ and the second from 4 to $5 \mathrm{~m}$. The plants with height of 3 to $4 \mathrm{~m}$ were Citrus x latifolia Tanaka ex Q. Jiménez, Citrus reticulata Blanco, Musa sapientum var. Champa Baker and Lippia graveolens Kunth and for the height of 4 to $5 \mathrm{~m}$ the following species Citrus aurantifolia Swingle and Citrus sinesis L. Osbek, were recorded; these species were presented on both plots.

\section{Estrato herbáceo}

These are plants measuring less than three meters, the species recorded in the $\mathrm{G} 1$ were Justicia spicigera Schltdl., Saccharum officinarum L. and Ruta chalepensis L., these species were different from those 
recorded in the G2 that included Zephyranthes carinata Herb., Chrysanthemum leucanthemum L., Ocimum micranthum Willd and Petiveria alliacea L.

\section{Estructura horizontal}

The horizontal structure describes the arrangement and distribution of the components of the family plot were, the house room, laundry room, chicken coop and the projection of the treetop. In the G1 it was observed that trees with cup diameters of 5 to $7.60 \mathrm{~m}$ are located near the house room less than $10 \mathrm{~m}$, the laundry room is located under shade $6 \mathrm{~m}$ and the chicken coop $12 \mathrm{~m}$ away from the house room, these components are located in the back (South) of the house room by decision of the family members. For $\mathrm{G} 2$, species with the largest diameter projection ( 9 to $12.2 \mathrm{~m}$ ) are located $20 \mathrm{~m}$ at the back of the house (West) (Fig. 3A and 3B).

\section{Discussion}

The participation of women in the family gardens of Tixmucuy, Campeche, play a decisive role in improving food security, ensuring that the household has an adequate supply of plant and animal food (Wodajo et al., 2020). In general, housewives average 45.3 years, the family are usually comprised of 3.9 members on average, and they manage a plot with an average extension of $1,156.04 \mathrm{~m}^{2}$. These data are consistent with those suggested by Poot-Pool, van der Wal, Flores-Guido, Pat-Fernández, \& EsparzaOlguín, (2012), who financially stratify the Mayan peasant families of Pomuch, Campeche, Mexico and their influence on family orchards, presented an average area of $1,262 \mathrm{~m}^{2}$ in the orchards of poor and wealthy families. In this same sense Salazar-Barrientos, Magaña-Magaña, \& Latournerie-Moreno (2015) reported that family transfers present in the community of Tixkokob, Yucatan, Mexico had an extension of $1,201 \mathrm{~m}^{2}$ and provided a part of the food required by families. In addition, they emphasize that these agroecosystems promote the subsistence of the family nuclei, through the integration of families. Within the family strategies for the maintenance of the orchard, roles have been defined for each member. Chablé Pascual et al. (2015) mention that in Chontalpa, Tabasco, Mexico planting, cleaning and irrigation activities are carried out by women, while men have temporary participation in maintenance activities. In this region, family plots have an extension of $4,616.11 \mathrm{~m}^{2}$ and an average establishment of 11.6 to 31.2 years, the largest plots having been passed from generation to generation. The people in charge of garden care are middle-aged women and older men, while the young people of the family study and working-age men have extra-farm jobs, this phenomenon was already been observed by Pulido-Salas et al. (2017). Likewise, in Cárdenas, Tabasco, México, Bautista-García, Sol-Sánchez, Velázquez-Martínez, \& Llanderal-Ocampo, (2017) Bautista-García, Sol-Sánchez, Velázquez-Martínez, \& Llanderal-Ocampo, (2017) comment that family orchards are managed by older relatives, who carryout planting, irrigation, pruning, cleaning and harvesting activities. The orchards of José María Morelos, Quintana Roo, Mexico, are established on property with private and ejidal land tenure, and have an extension ranging from 400 to $2,700 \mathrm{~m}^{2}$ and 25 years of establishment and use. This suggests that in the rural towns of Campeche 
there is less access to areas for the implementation of family plots, so the arrangement of the elements is carried out based on short- and long-term planning that allows efficient use of available resources.

In relation to plant diversity, 470 species and nine uses were reported, where plants are mainly used as ornamentals and food for humans. In the plots of José María Morelos, Quintana Roo, Mexico, fewer plant species and botanical families were found, 72 and 40 respectively. These species were used in 10 different forms: food, ceremonial, condiment, construction, fodding, medicinal, sale, shadow, ornate and utensil making. $58.3 \%$ of plant species are used as food, highlighting this as the main function of the solars studied, followed by medicinal use with $16.6 \%$ (Pulido-Salas et al., 2017). In Chemblas and Laureles, Campeche, México, a similar number of species and families are reported with 86 and 41, respectively. The remaining uses conferred on plant species coincide with those found in this study, the main being: food and ornamental with 42 and $34 \%$. However, the less common uses differ with those observed in this study as magical-religious, tutor of another plant species, fishing art, pest control and protection (Góngora-Chin et al., 2016). On the other hand, Chablé Pascual et al., 2015) reported a diversity of plant species greater than that found in this study when they analyzed the family plots of Chontalpa in Tabasco, Mexico, in which they found 330 plant species where it was nine categories of use were observed, and the main ones were ornamental, medicinal and for 138, 115 and 98 species, respectively. In the same study, the family plots of Cárdenas, Tabasco, México Bautista-García et al. (2017) recorded 1, 968 plants of 203 species and 69 different botanical families, but coincided with this study as the botanical families Fabaceae and Rutaceae being the most abundant with the main ornamental uses and as food.

The diversity index in the orchards of Tixmucuy, Campeche was of $\mathrm{H}^{\prime}=3.436$ on average; in this sense Salazar-Barrientos et al. (2015) reported that the Tixkokob solars, Yucatán, México, present the same trend with a diversity index of $\mathrm{H}^{\prime}=4.262$, The main use of these species is ornamental followed by consumption. The botanical family Rutaceae with the species stands out: Citrus aurantium L. (35.7\%), Citrus sinensis Osbeck (35\%), Citrus aurantifolia Swingle (25.8\%), Citrus limonia Osbeck (18.2\%) and Citrus paradisi Max (18.2\%). The above also matches reported by Poot-Pool et al. (2012) in family plots of the community of Pomuch, Campeche, Mexico, where they observed that poor families include native plant species in their plots for uses such as fodder, medicine, firewood, construction wood and carpentry whereas wealthy families included fruit trees and ornamental plants. Comparing with the results of this study it can be assumed that the G1 plots belong to rich families, while the solars of the G2 belong to poor families. This behavior can be explained according to Bautista-García et al. (2017), where rich families attach greater economic importance to the species they have on the plots and use them for the sale of ornamental and fruit plants.

In the animal component, we found three species of birds, the main being Gallus domesticus $\mathrm{L}$. The largest number of domestic animal species in the $\mathrm{G} 1$ was due to access to government programmes that subsidize packages of birds for breeding on family plots (Poot-Pool et al., 2012); These programmes function as incentives to improve food security in rural families by increasing the production of animal food and improving the nutritional level of family members (Wodajo et al., 2020).

Page $12 / 19$ 
The poultry was mainly used for the production of food and food-sale (Gutiérrez-Triay et al., 2007). Domestic birds represent $76 \%$ of the animal species present in the family plots of seven municipalities of Campeche, Mexico (Flota-Bañuelos et al., 2016), 75\% in Chemblas and The Los Laureles, Campeche, México (Góngora-Chin et al., 2016) and 98.3\% en Tetiz Yucatán, México (Salazar-Barrientos et al., 2015), These figures make it clear that the fundamental role of these animal species is obtaining protein food products (meat and egg), as well as economic income from the sale of surpluses in the family plots of the study region (Candelaria-Martínez, Ramírez-Mella, Flota-Bañuelos, \& Dorantes-Jiménez, 2016). The results of this study differ with what is reported for family plots of Chontalpa and Cardenas, Tabasco, where a greater number of animal species were recorded: Ovis aries, Suss crofa, Gallus, Anas eranser, Meleagris gallipavo, all of them with food use (Bautista-García et al., 2017; Chablé Pascual et al., 2015; Góngora-Chin et al., 2016), the species Anas boschas and Bos indicus were only reported for Chontalpa, and are bred for consumption by the family and sale (Chablé Pascual et al., 2015). Therefore, animals are an important complementary component in family plots and their use is linked to the provision of food to the family (Salazar-Barrientos et al., 2015). With regard to wildlife on the plots of the state of Campeche, Mexico, it is common for rural families to maintain wildlife species such as Dendrocygna autumnalis, Agouti paca, Pecari tajacu, Ctenosaura pectinata in corrals designed for this purpose within the space occupied by family plots and are mainly used as mascot and food (Ramírez-Mella, Candelaria-Martínez, Dorantes-Jiménez, Tarango-Arámbula, \& Flota-Bañuelos, 2016). Wild species such as Amazona albifrons, Columba sp, Aratinga sp., with ornamental use and Agouti paca as a pet in the Chontalpa, Tabasco, México (Chablé Pascual et al., 2015), Leptotila verreauxi, Columba livia, Zenaida asiática and Melopsittacus undulatus as food and pet, in the town of Los Laureles and Chemblas, Campeche, México, and Poicephalus sp., as ornate in Cárdenas, Tabasco, México (Bautista-García et al., 2017).

In the vertical structure of the plots, the strata, arboreal, shrub and herbaceous were differentiated. In the tree stratum, there were heights of $17 \mathrm{~m}$. These species coincide with those found in the family plots of José María Morelos, Quintana Roo, México (Pulido-Salas et al., 2017) and the Chontalpa, Tabasco, México, except for the species Cordia alliodora that reaches up to $19 \mathrm{~m}$ (Chablé Pascual et al., 2015). The shrub stratum were present different species of citrus, with average heights of $4 \mathrm{~m}$. These heights are presented in the same way for the plots of Chontalpa, Tabasco, México (Chablé Pascual et al., 2015), the species are similar, excluding Coffea arabica and Theobroma cacao, the latter is part of the sociocultural environment of the state. Finally, the eastern herbaceous stratum, mainly the species of medicinal use (Ruta chalepensis, Lippia graveolens and Catharanthus roseus, among other) and edibles (Cucurbita moschata and Ipomea batatas) (Chablé Pascual et al., 2015), are found, usually located in the surrounding part or near the house (Salazar-Barrientos et al., 2015).

In the horizontal structure of the orchards is defined by the management that is established within this space, the logic of facilitating the work that is carried out on the plot predominates. Likewise, what was observed in this study coincides with what was reported by Pulido-Salas et al. (2017) who detected that the trees were arranged near the house, to provide shade, and differ with what was reported by Chablé Pascual et al. (2015) who report for the family plots of the Chontalpa a total linkage of the arrangement 
of the components of this space with the presence of cocoa and its dependence on envelope by a higher tree stratum.

\section{Conclusions}

In the family plots of the community of Tixmucuy, Campeche, Mexico there is a wide diversity of plant species, which serve mainly as food. The abundance, richness and arrangement of species depends on the age and extent of the family plot. The vertical structure of the plots is dominated by the tree, shrub and herbaceous strata the characteristics of each stratum are defined by the age of the plot, the horizontal structure maintains an arrangement and distribution of the biotic and abiotic components that is given by the logic of the management and control of the system. Animal species are a complementary component in the family plots of Tixmucuy, Campeche, represents fewer uses than the plant component and the infrastructure for their containment is located further away from the room house, while the spaces in which daily work is carried out are located closer and accessible.

\section{Declarations}

\section{Availability of data and material}

All data generated or analyzed during this study are included in this published article.

\section{Ethics approval and consent to participate}

No ethical approval was needed for this study. Prior to data collection, participants gave oral consent to participate in the study.

\section{Consent for publication}

The respondents were informed that their opinions were to be published in a scientific paper and gave their approval.

\section{Competing interests}

The authors declare that they don't have competing interests.

\section{Funding}

To the National Council of Science and Technology (CONACYT) for the scholarship number 672808 granted to the first author to carry out the master's studies in science. The CONACYT-2181 Chairs project 
"Agroecological Strategies for Food Security in Rural Areas of Campeche".

\section{Contributions}

GJG, BCM, CFB designed the study. GJG performed the field work, data collection, and statistical analyzes. All authors wrote and approved the final manuscript.

\section{Acknowledgments}

To the Colegio de Postgraduados Campus Campeche, to the National Council of Science and Technology (CONACYT) and especially to the participating families of Tixmucuy, Campeche for their support and collaboration to carry out the presentwork.

\section{Publisher's Note}

Springer Nature remains neutral with regard to jurisdictional claims in published maps and institutional affiliations

\section{References}

1. Abebe T, Sterck FJ, Wiersum KF, Bongers F. Diversity, composition and density of trees and shrubs in agroforestry homegardens in Southern Ethiopia. Agrofor Syst. 2013;87(6):1283-93. https://doi.org/10.1007/s10457-013-9637-6.

2. Albuquerque UP, Andrade LHC, Caballero J. Structure and floristics of homegardens in Northeastern Brazil. J Arid Environ. 2005;62(3):491-506. https://doi.org/10.1016/j.jaridenv.2005.01.003.

3. Bautista-García G, Sol-Sánchez Á, Velázquez-Martínez A, Llanderal-Ocampo T. (2017). Composición florística e importancia socioeconómica de los huertos familiares del Ejido La Encrucijada, Cárdenas, Tabasco. Revista Mexicana de Ciencias Agrícolas, (14), 2725. https://doi.org/10.29312/remexca.v0i14.441.

4. Caballero-Serrano V, Onaindia M, Alday JG, Caballero D, Carrasco JC, McLaren B, Amigo J. Plant diversity and ecosystem services in Amazonian homegardens of Ecuador. Agr Ecosyst Environ. 2016;225:116-25. https://doi.org/10.1016/J.AGEE.2016.04.005.

5. Candelaria-Martínez B, Ramírez-Mella M, Flota-Bañuelos C, Dorantes-Jiménez J. Recursos genéticos "Criollos" de zonas rurales de Campeche, México. Agroproductividad. 2016;9(9):29-32.

6. Cano Contreras E, Siqueiros Delgado M. Aproximación al Huerto Familiar de Clima Semiárido: Caracterización del Solar en El Ocote. Aguascalientes México Etnobiología. 2009;7(1):45-55.

7. Chablé Pascual R, Palma López D, Vázquez Navarrete C, Ruiz Rosado O, Mariaca Méndez R, Ascencio Rivera J. Estructura, diversidad y uso de las especies en huertos familiares de la Chontalpa, 
Tabasco, México. Ecosistemas y Recursos Agropecuarios. 2015;2(4):23-39.

8. COMO SISTEMA SOCIAL Y AGROECOSISTEMA PATIO FAMILIAR: MODELO TEÓRICO CONCEPTUAL DESDE LA TEORIA LUHMANNIANA † [FAMILY AS A SOCIAL SYSTEM AND HOMEGARDEN AGROECOSYSTEM

Revisión [Review] FAMILIA

Cruz-Bautista P, Casanova-Pérez L, Martínez-Dávila P, Flores-Martínez J, C., \& Villegas-Rodríguez I. (2019). Revisión [Review] FAMILIA COMO SISTEMA SOCIAL Y AGROECOSISTEMA PATIO FAMILIAR: MODELO TEÓRICO CONCEPTUAL DESDE LA TEORIA LUHMANNIANA † [FAMILY AS A SOCIAL SYSTEM AND HOMEGARDEN AGROECOSYSTEM. CONCEPTUAL THEORETICAL MODEL FROM THE LUHMANNIAN THEORY]. Tropical Subtropical Agroecosystems, 22, 713-22.

9. Eisenhardt KM. Building Theories from Case Study Research. Acad Manag Rev. 1989;14(4):532-50. https://doi.org/10.5465/amr.1989.4308385.

10. Fernandes ECM, Nair PKR. An evaluation of the structure and function of tropical homegardens. Agric Syst. 1986;21(4):279-310. https://doi.org/10.1016/0308-521X(86)90104-6.

11. Flota-Bañuelos $C$, Ramírez-Mella M, Dorantes-Jiménez J, José-García G, Bautista-Ortega J, PérezHernández P, Candelaria-Martínez B (2016). Descripción Y Diversidad De Solares Familiares En Zonas Rurales De Campeche M. Description and Diversity of Family Backyards in Rural Zones of Campeche, México., 9(9), 38-43. Retrieved from http://search.ebscohost.com/login.aspx? direct=true \&db=fap\&AN=119147305\&site=ehost-live.

12. García E. (1973). Modificaciones al sistema de clasificación climática de Köppen. In Instituto de Geografía.

13. Góngora-Chin RE, Flores-Guido S, Ruenes-Morales M del Aguilar-Cordero R, García-López WdelJ, Góngora-Chin JE, RE, ... García-López, J. E. (2016). Ecosistemas y recursos agropecuarios. In Ecosistemas y recursos agropecuarios (Vol. 3). Retrieved from http://www.scielo.org.mx/scielo.php? script=sci_arttext\&pid=S2007-90282016000300379\&lng=es\&nrm=iso\&tlng=pt.

14. González-Ortiz F, Pérez-Magaña A, Ocampo-Fletes I, Paredes-Sánchez J, de la Rosa-Peñaloza P. Contribuciones de la producción en traspatio a los grupos domésticos campesinos. Estudios Sociales: Revista de Investigación Científica. 2014;22(44):147-70.

15. Gutiérrez-Triay MA, Segura-Correa JC, López-Burgos L, Santos-Flores J, Santos-Ricalde RH, Sarmiento-Franco L, ... Molina-Canul G. Tropical Subtropical Agroecosystems. 2007;7(3):217-24. https://www.redalyc.org/pdf/939/93970308.pdf.

16. Huerta E, van der Wal H. Soil macroinvertebrates' abundance and diversity in home gardens in Tabasco, Mexico, vary with soil texture, organic matter and vegetation cover. European Journal of Soil Biology. 2012;50:68-75. https://doi.org/10.1016/j.ejsobi.2011.12.007.

17. INEGI (Instituto Nacional de Estadística y Geografía e Información). (2015). Espacio y datos de México. Retrieved from https://www.inegi.org.mx/app/mapa/espacioydatos/default.aspx? $\mathrm{ag}=040020105$. 
18. Moreno-calles Al, Casas A, Rivero-romero AD, Romero-bautista YA, Rangel-landa S, Fisher-ortíz RA, ... Vallejo-ramos M. (2016). Ethnoagroforestry: integration of biocultural diversity for food sovereignty in Mexico. J Ethnobiol Ethnomed, 1-21. https://doi.org/10.1186/s13002-016-0127-6.

19. Poot-Pool WS, van der Wal H, Flores-Guido S, Pat-Fernández JM, Esparza-Olguín L. Estratificación económica diferencia huertos familiares en el poblado Maya de Pomuch,México. Econ Bot. 2012;66(3):264-75. https://doi.org/10.1007/s12231-012-9206-3.

20. Pulido-Salas MT, de Jesús Ordóñez Díaz M, de Dios HC. (2017). FLORA, USOS Y ALGUNAS CAUSALES DE CAMBIO EN QUINCE HUERTOS FAMILIARES EN EL MUNICIPIO DE JOSÉ MARÍA MORELOS. QUINTANA ROO, MÉXICO. Península, 12(1), 119-45. https://doi.org/10.1016/J.PNSLA.2017.01.006.

21. Ramírez-Mella M, Candelaria-Martínez B, Dorantes-Jiménez J, Tarango-Arámbula LA, Flota-Bañuelos C. (2016). USO Y APROVECHAMIENTO DE FAUNA SILVESTRE EN ZONAS RURALES DE CAMPECHE, MÉXICO. Agroproductividad, 9(9).

22. Rangel-landa S, Casas A, Rivera-lozoya E, Torres-garcía I, Vallejo-ramos M. (2016). Ixcatec ethnoecology: plant management and biocultural heritage in Oaxaca, Mexico. In Journal of Ethnobiology and Ethnomedicine. https://doi.org/10.1186/s13002-016-0101-3.

23. Salazar-Barrientos LdeL, Magaña-Magaña MA, Latournerie-Moreno L. (2015). Agricultura, sociedad y desarrollo. Agricultura, Sociedad y Desarrollo, 12(1), 1-14. Retrieved from http://www.scielo.org.mx/scielo.php?script=sci_arttext\&pid=S1870$54722015000100001 \&$ lng =es\&nrm=iso\&tlng=es.

24. Wodajo HD, Gemeda BA, Kinati W, Mulem AA, van Eerdewijk A, Wieland B. Contribution of small ruminants to food security for Ethiopian smallholder farmers. Small Ruminant Research. 2020;184:106064. https://doi.org/10.1016/J.SMALLRUMRES.2020.106064.

25. 10.1016/j.foodpol.2010.11.013

Wossen T, Berger T, Sonnino R, Lozano Torres C, Schneider S, Sherwood S, ... Alayón Gamboa JA e. d. (2014). El huerto familiar: un sistema socioecológico y biocultural para sustentar los modos de vida campesinos en Calakmul, México. In Food Policy (Vol. 36). https://doi.org/10.1016/j.foodpol.2010.11.013.

\section{Figures}




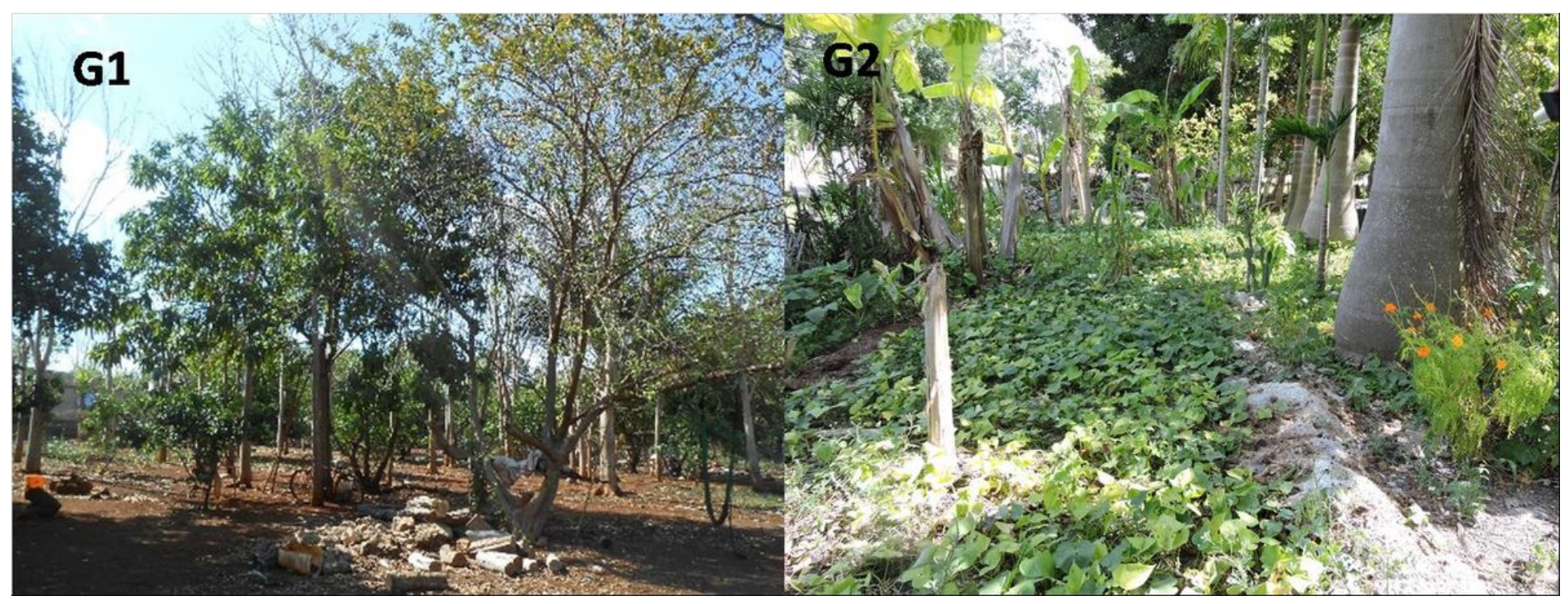

Figure 1

Characteristic family plots of Tixmucuy, Campeche. G1 (group 1) and G2 (group 2)

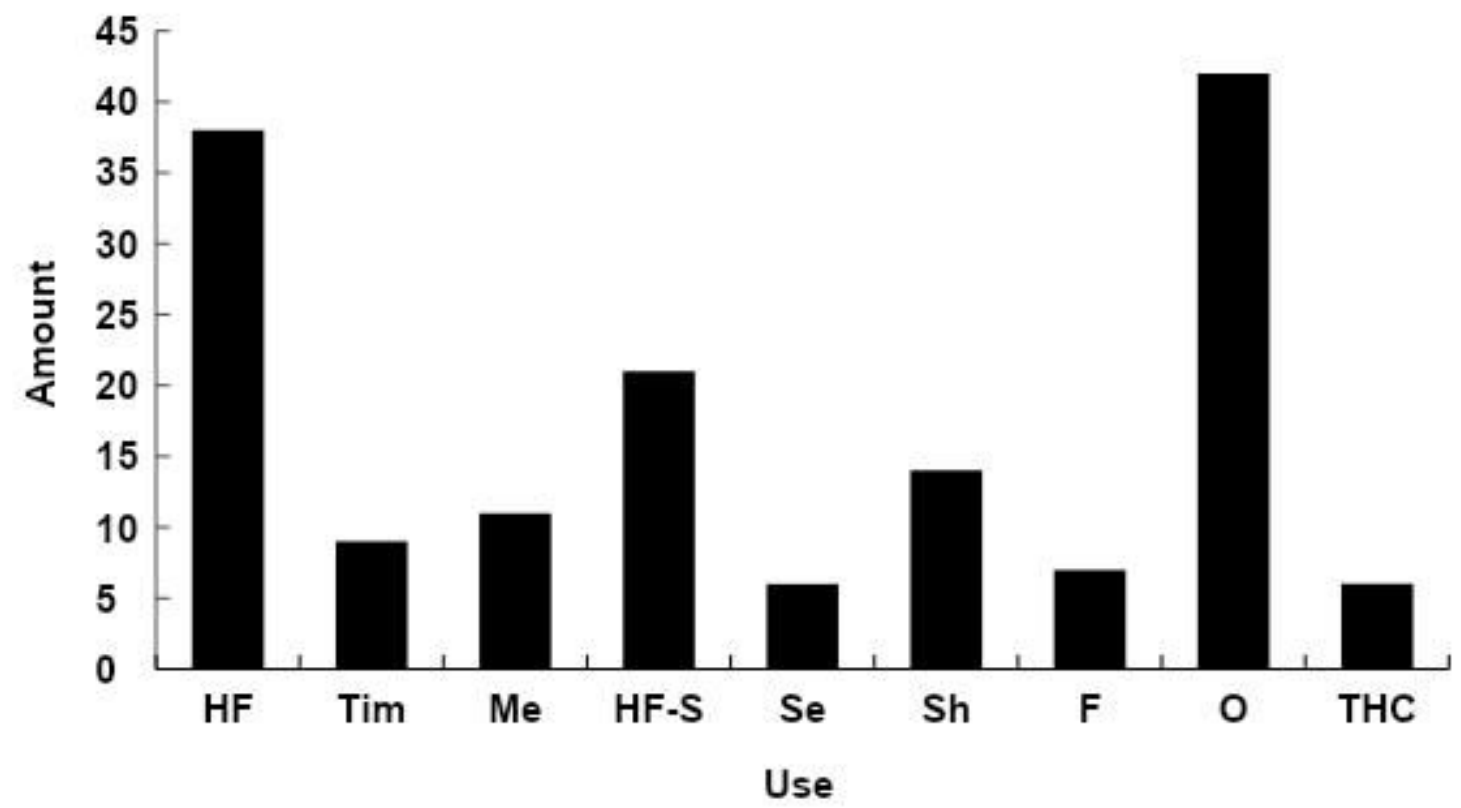

Figure 2

Uses of the plant component in family plots in rural areas of the state of Campeche, México. $A=$ human food, $\mathrm{O}=$ ornament, $\mathrm{Ma}=$ timber, $\mathrm{A}-\mathrm{V}=$ human food and sale, $\mathrm{C}=$ seasoning, $\mathrm{S}=\mathrm{Shady}, \mathrm{Me}=$ medicine, $\mathrm{Cb}=$ fuel and $\mathrm{Cvt}=$ traditional housing construction 


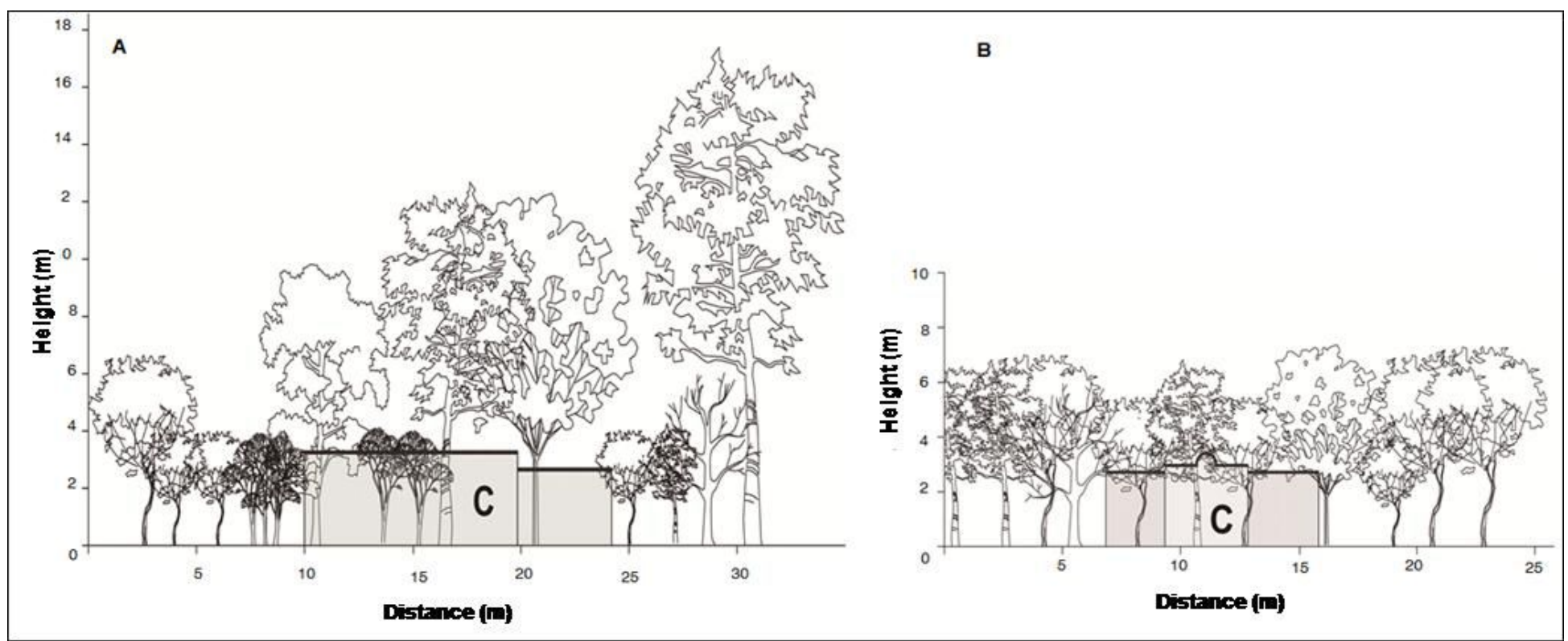

Figure 3

A) Vertical structure of the homegarden of G2 and B) Vertical structure of the homegarden of G1

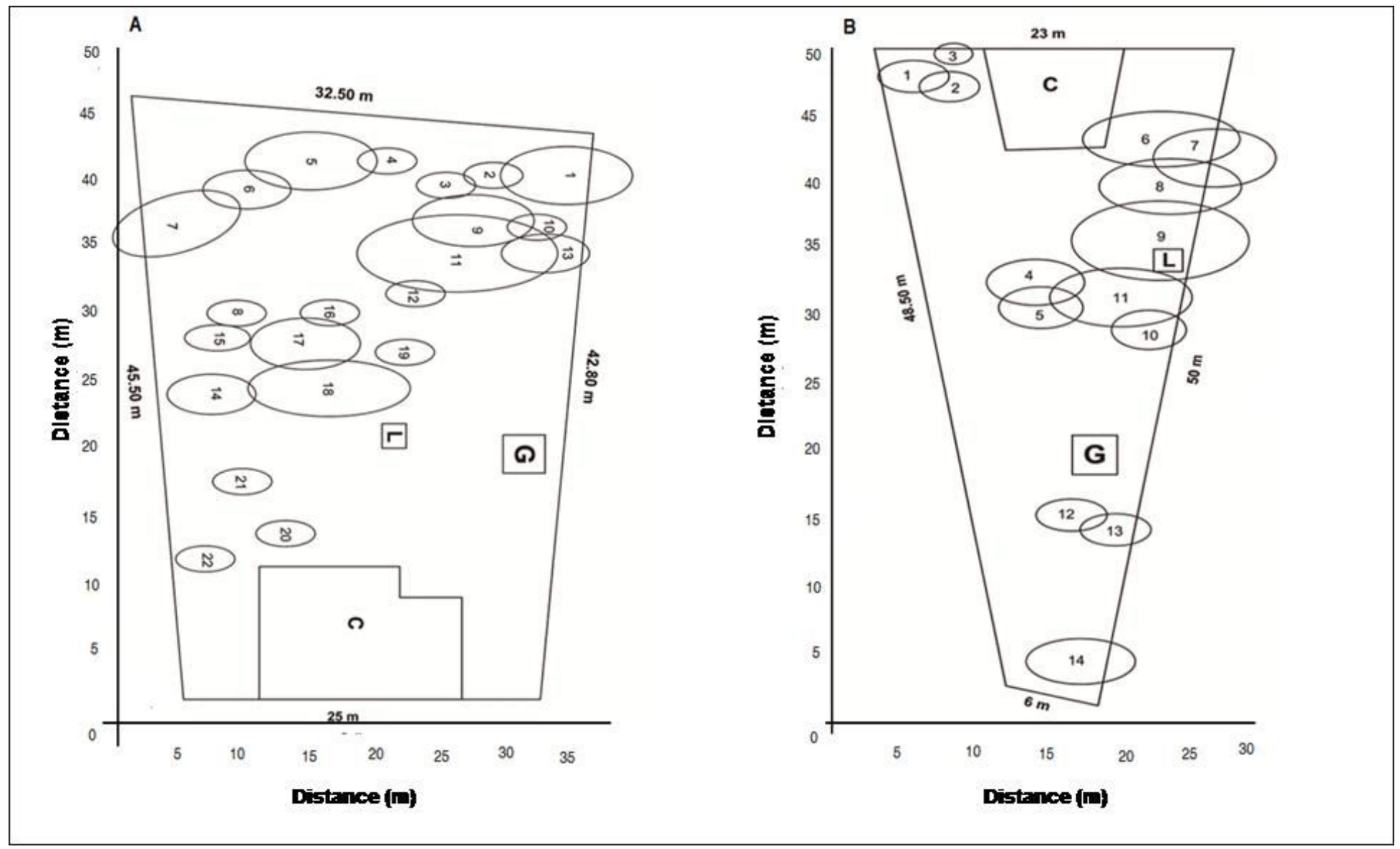

Figure 4

A) Horizontal structure of the homegarden of G2 and B) Horizontal structure of the homegarden of G1. Literals in figure: $\mathrm{G}=$ henhouse, $\mathrm{L}=$ laundry, $\mathrm{C}=$ house, $1-22$ = treetops 